\title{
ECONOMIC AND ENERGY EFFICIENCY \\ OF MICROBIAL PREPARATIONS AT CULTIVATION \\ OF YELLOW LUPINE ON THE BACKGROUND OF VIRAL INFECTION
}

\author{
O. V. Pyrig, Yu. M. Khalep, V. A. Bardakov
}

In Ukraine narrow leaves virus is the most common and most harmful yellow lupine viral disease, the causative agent of which is Bean yellow mosaic virus (Bean yellow mosaic virus, BYMV) [1]. The lesion of lupine plants with narrow leaves virus negatively impacts the growth and development of culture, in particular, leads to significant changes in the formation and functioning of nitrogen-fixing symbiosis Rhizobium lupini - Lupinus luteus L. - the nodulation activity and weight of root nodules decrease, nitrogenase activity of symbiotic system reduces. The loss of yellow lupine grain yield, when plants are infected in hearted state, reaches $95 \%$, in the bud state early flowering - 56\% [2]. Significant distribution of narrow leaves virus on yellow lupine crops determines the relevance of finding ways to increase plant resistance to viral destruction.

Recently, more and more prevalent becomes the use of efficient and environmentally friendly regulators of plant growth and development, microbial preparations that improve crop resistance to diseases, including viral, and improving the implementation of performance capacity embedded in the plants [3].

In previous studies, we studied the impact of biological preparations on the course of infection in yellow lupine plants of Prohresyvnyi variety caused by Bean yellow mosaic virus. When growing yellow lupine in the conditions of viral infection, the use of biological preparations contributes to the reduction of spread and development of narrow leaves virus on culture crops. The highest inhibitory effect on BYMV was detected when using Ryzohumin and Hetomik. Pre-plant inoculation with biological preparations contributes to the activation of growth and development of plants affected by BYMV, positively affects photosynthetic and nitrogen-fixing activity, culture production process (grain yield increase by 53\%) [4; 5].

Along with the investigated aspects of the effectiveness of these preparations, the economic efficiency of their use in yellow lupine growing technologies requires separate analysis. After all, this aspect is one of the key ones in the creating of market success of any production facility, in this case Ryzohumin and Hetomik.

Materials and methods. Official and well-known methods were used as the methodological basis for calculations of economic efficiency of preparations [6;7], based on the traditional approach of comparing the results of certain agricultural technique with the expenses related to it.

During the simulation of expenses manufacturing operations and resource consumption were adopted by the standards of National Scientific Centre "Institute of Agrarian Economics" of NAAS [8; 9] with a corresponding adjustment of operations (no fertilization, etc.) excluding additional direct and overhead costs associated with the use of study preparations.

The determination of the impact of factors on cost-effectiveness was performed using deterministic methods of factor analysis [10].

To determine the quantitative impact of factors change on the deviation of the cost of 1 ton of grain such a deterministic two-factor model was used:

$$
C=\frac{B}{y},
$$

where $\mathrm{C}$ - cost of 1 ton of grain, UAH;

B - cash costs per 1 ha of sowing, UAH; $\mathrm{Y}$ - grain yield, $\mathrm{t} / \mathrm{ha}$.

To determine the quantitative impact of factors on the deviation of profit margins per 1 ha of sowing such a deterministic three-factor model was used:

$$
\Pi=Ц \times Y-B,
$$

where $\Pi$ - profit from 1 ha of crops, UAH;

$Ц$ - price of 1 ton of grain, UAH;

$\mathrm{Y}$ - grain yield, $\mathrm{t} / \mathrm{ha}$;

$\mathrm{B}$ - cash costs per 1 ha of sowing, UAH.

To determine their quantitative effect on 
profitability level deviation the traditional economic model of profitability $(\mathrm{P}=\Pi: \mathrm{B} x$ $100 \%$ ) was turned to the form suitable for the separation of influence of investigated factors:

$$
P=\frac{\Pi}{B} \times 100=\frac{Ц \times Y-B}{B} \times 100=\left(\frac{\lfloor\times Y}{B}-1\right) \times 100,
$$

where $\mathrm{P}$ - profitability level, $\%$;

$\Pi$ - profit per 1 ha of sowing, UAH;

$\mathrm{B}$ - cash costs per 1 ha of sowing, UAH;

$Ц$ - price of 1 ton of grain, UAH;

$\mathrm{y}$ - grain yield, $\mathrm{t} / \mathrm{ha}$.

The defining of energy efficiency evaluation was carried out by appropriate methods [11-13]. For this, production operations (working hours of machinery and tools) and the resources consumption (which were used for the economic assessment) were transferred into energy equivalents.

From the results of the economic study of the effectiveness of Ryzohumin and Hetomik in the technology of growing lupine for grain it can be concluded that the major factors that directly affect it (first-order factors) is the productivity level and the amount of the costs associated with the use of preparations at the rate of 1 ha of cultivated area. Since both of these indicators change their values in different versions of technologies, it may be appropriate to determine the quantitative impact of these factors on the change of major indicators of economic efficiency of grain lupine: the cost of 1 ton of product, the profit per 1 ha of crops and profitability.
In general, we can conclude that the use of Ryzohumin and Hetomik in the technologies of growing lupine for grain the increase in economic efficiency level by all major indicators is due to outstripping productivity growth in comparison with the growth of cost per 1 ha of crops. It should be focused on the efficiency of the use of these preparations compared with other means of production, which is especially relevant in the current economic conditions.

The results of indicators analysis can lead to a conclusion about high energy efficiency of Hetomik and Ryzohumin in the production of lupine for grain. Thus, energy efficiency ratios (both general and by primary products) while using the investigated preparations increased almost by one and half compared with a control variant, and the additional yield energy 38.4 times exceeds the energy consumption for its receipt using Ryzohumin and 8 times using Hetomik. At this the application of Ryzohumin has a slightly higher level of energy efficiency compared to Hetomik.

Overall, the results of the analysis of economic and energy efficiency of Ryzohumin and Hetomik application in the technology of growing lupine for grain, can lead to the conclusion that these preparations are highly effective both in economic and energy aspects even in the conditions of significant spread of viral infection. 